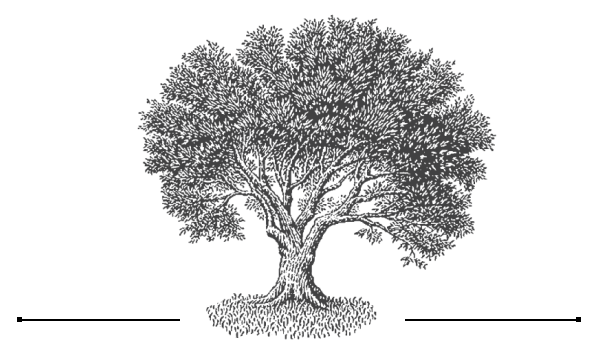

\section{Пастернак и}

Клопшток

(о стихотворении

Б. Пастернака

“Цельною иьдиной из

дымности вынут. ..")

\section{Роберта Сальваторе}

Мессинский университет

Мессина, Италия

\section{Boris Pasternak and Friedrich Gottlieb Klopstock (about Pasternak's Poem The Starry River of a Week Ago)}

\author{
Roberta Salvatore \\ University of Messina \\ Messina, Italy
}

\title{
Pезюме
}

В данной статье на основе подробного анализа стихотворения Б. Пастернака “Цельною льдиной. . .” (1917) доказывается, что описанный в нем пейзаж представляет собой изображение художественного процесса и размышление о его сущности. Предложенное толкование подкрепляется и отсылками к прозе и письмам поэта, и образной перекличкой пастернаковского текста с группой из пяти стихотворений $\Phi$. Кдопштока, где фигурное катание служит метафорой творчества. Именно этот "цикл" Клопштока в немецкой иитературе кдадет начало специфической традиции изображения этого спорта, в котором катание симводизирует порыв и опасность вдохновения. В закдючительной части статьи обсуждается вероятность знакомства Пастернака с творчеством Кдопштока и идейные перекдички между этими двумя поэтами.

\section{Ключевые слова}

Борис Пастернак, Фридрих Готлиб Клопшток, фигурное катание как образ творчества, поэтика

\section{Abstract}

The aim of this paper is to demonstrate that Boris Pasternak's poem The Starry River of a Week Ago (1917) is a description of the creation process and a reflection on the nature of this process. To support this view, attention will be drawn to some 
significant sets of images and themes in this text that are found also in a group of five poems by Friedrich Gottlieb Klopstock, in which ice-skating functions as a metaphor of creation. These poems will give rise to a specific tradition within German poetry where ice-skating is symbolic of both the rapture and the risk of inspiration. In the last part of the paper it will be shown that, although there is no evidence of Pasternak's acquaintance with Klopstock's poetry, his thorough knowledge of German language and literature leaves little doubt about this acquaintance. Moreover, it is possible to find a number of affinities in the way of thinking of these two writers.

\section{Keywords}

Boris Pasternak, Friedrich Gottlieb Klopstock, ice-skating as a metaphor of creation, poetics

1 Цельною льдиной из дымности вынут

Ставший с неделю звездный поток.

3 Клуб конькобежцев вверху опрокинут:

4 Чокается со звонкою ночью каток.

5 Реже-реже-ре-же ступай, конькобежец,

6 В беге ссекая шаг свысока.

7 На повороте созвездьем врежется

8 В небо Норвегии скрежет конька.

9 Воздух железом к ночи прикован.

10 О конькобежцы! Там - все равно,

11 Что, как орбиты змеи очковой

12 Ночь на земле, и как кость домино;

13 Что языком обомлевшей легавой

14 Месяц к скобе примерзает; что рты,

15 Как у фальшивомонетчиков, - лавой

16 Дух захватившего льда налиты.

Это стихотворение входит в книгу “Поверх барьеров” (1917). С новым названием “Зимнее небо” и незначительными изменениями в стихах 9 и 11 оно вошло также в переработанную версию этой книги 1929 г. Текст почти не привлекал внимания исследователей: видимо, яркость описания и загадочность некоторых образов мешали подступиться к его глубинному, эмоциональному содержаниюํ. Всё же комментаторы последнего

1 Единственный развернутый анализ этого текста принадлежит Б. Арутюновой [AROUTUNOVA 1979]. 
издания Пастернака очень точно отметили, что “тема отражения неба в пруду [. . .] есть по существу тема искусства и жизни, иными словами, существования двух миров” [ПАстерНАК 2003, 1: 439] ${ }^{2}$. Нам хотелось бы развить эту мысль, исходя прежде всего из образа конькобежца. Мы постараемся доказать, что главной темой этого стихотворения является тема творчества, воспринятого одновременно как судьба художника и как результат его дарования. Именно образ конькобежца становится у Пастернака воплощением сложной связи между действительностью, художником и его произведением. Начнем с краткого разбора этого текста.

\section{1. ЦельнОЮ ЛьДинОЙ Из ДьмнОсти вынут.}

Стихотворение представляет собой развернутое уподобление катка звездному небу, причем пространственная смежность этих двух реалий обусловливает их наложение 3 . Первая строфа, где задается основная тема, целиком построена на принципе перевернутости. Этот прием обнаруживается на разных уровнях четверостишия. Во-первых, главная метафора представлена здесь перевернутым процессом: от результата, “цельной льдины” - через застилающий сначала эту будущую льдину туман - к первоначальному “жидкому состоянию” звездного потока 4 . Итак, небо-поток показано динамически, в обратном порядке своего оформления. Наряду с обращением временного порядка происходит и двоякая пространственная инверсия: во втором двустишии каток не только как бы поднимается на небо, устраняя оппозицию верха и низа, но и предстает в зеркальном отражении. Во-вторых, строй предложения явно призван обманывать читательские ожидания. В самом деле, на протяжении всего первого двустишия, казалось бы, описывается какая-то ледяная поверхность, и только в самом его конце выражение “звездный поток” превращает льдину из детали реального пейзажа в метафору, которая включается в более широкий смысловой план. Это переосмысление, однако, не опровергает первоначального понимания текста: прямое значение картины сосуществует с переносным, и это внутреннее противоречие поддерживается определением “с неделю”, плохо

2 В дальнейшем все тексты Пастернака приводятся по этому изданию.

3 В частности, можно предположить, что ледяная поверхность сопоставляется с Млечным Путем. Наряду с визуальным сходством отметим здесь то, что прилагательное “млечный” в названии галактики хорошо согласуется и с жидким состоянием “звездного потока”, и с его затвердением, которое выражено причастием “ставший”. К тому же “дымность”, откуда выглядывает льдина, напоминает определение звездного скопления как “туманности”.

4 Образ ночного неба как воды и его ассоциация со льдом появляется уже в ранней ПроЗе ПАСТЕРНАКА [2004, 3: 352, 467]. 
связывающимся с описанием неба 5 . Превращению материи соответствует аналогичный процесс в языке: в то время как льдина возвращается к своему изначальному жидкому состоянию, “поток” в конце четверостишия неожиданно отождествляется со словом “каток”, создавая эффект паронимического сближения. В обоих случаях изменение формы означает и смену содержания: язык и действительность обнаруживают глубинное соответствие, потому что в них сходным образом выражается одно и то же явление. В таком преломлении каток, при всей своей предметности, представляет собой и пространство творчества, где действительность приобретает новую, более правдивую форму, и поэтому в нем отношения могут оказаться другими, перевернутыми ${ }^{6}$.

Построение первой строфы подчеркивает момент преображения, и тем самым подспудно вводит в текст тему творчества. На него намекают также аллюзии на Книгу Бытия: упоминание семи дней явно отсылает к сроку создания мира, равно как и наличие дыма, который у Пастернака часто ассоциируется с первозданностью вселенной ${ }^{7}$. Показывая образ в его развертывании, перевернутый порядок восстанавливает свежесть первичного узнавания мира и позволяет воспринимать произведение не только как результат, но и как динамический процесс.

Во второй строфе сопоставление ночного неба с катком развивается дальше, и следы коньков на льду уподобляются созвездиям. Опять-таки, невозможно определить основу сравнения и вспомогательный образ: правильнее толковать эти стихи как одновременное изображение двух совпадающих реалий ${ }^{8}$. Тема творческого перевоплощения действительности заложена также в соотнесения созвездия как символа судьбы со следами на льду в качестве реализации художественного знака. Их

5 Перевернутость изображения сближает небо с зеркалом, намекая на тему творческого перевоплощения действительности. Это сходство проявляется в пространственном перемещении, где смежность превращается в тождество. Однако каток и звездный поток не сливаются ни в конкретном, ни в языковом плане: они могут “чокаться” между собой, сохраняя свою отдаленность, и не образуют метафору, потому что не происходит прямого сдвига термина с одного предмета на другой. Троп осуществляется лишь в предметном плане, потому что в поэтическом пространстве смещается не слово или понятие, а сам каток.

6 Тост (“чокается”), скрепляющий соприкосновение неба и земли, по-новому подчеркивает представление звездного скопления как жидкого потока. Этот образ варьирует ключевую для Пастернака тему контакта человеческого и божественного миров; об этом см. [Жолковский 2011: § 2].

7 См., например, стихотворения “Любимая, жуть!. . . ” и “Степь”; ср. также первое стихотворение цикла “Болезнь”, где в седьмой день заболевания происходит выздоровление, символизирующее чудотворное влияние искусства.

8 Текст построен на метонимических сдвигах: существительное “скрежет” (конька) заменяет более привычное выражение “скрежещущий конек”, а “Небо Норвегии” метонимически отсылает к определению гоночных коньков как “норвежских”; cM. [AROUTUNOvA 1979: 211; ПАСТЕРНАК 2003, 1: 440]. 
объединяет образ линии: в качестве созвездия она указывает на предназначение подлинного художника, но одновременно является и плодом таланта, новообретенной формой произведения 9 . В линии творение и творец совпадают.

Третья строфа описывает воздействие морозного воздуха на конькобежцев и вид земли с высоты перевернутого в небе катка. В первом стихе образ прикованного воздуха восходит, вероятно, к характерной для русской народной культуры ассоциации мороза с ковкой: славяне представляли себе зиму в виде кузнеца, который заковывает природу цепями и строит ледяные мосты ${ }^{10}$. Это четверостишие вводит тему контраста мороза и тепла, которая и развивается в конце стихотворения: образ жгучего мороза, превращающего холод в жар, передает способность искусства оживлять материю ${ }^{11}$.

Труднее понять конец четверостишия, где ночь сравнивается с орбитами очковой змеи и с костью домино. Эти образы служат хорошим примером того, как часто поэзия Пастернака озадачивает нас неуловимостью связей, скрепляющих образы. Если, как здесь, отсутствует даже пространственная смежность сопоставляемых элементов, упорядоченность образов может показаться столь случайной, что ставится под сомнение сама логичность развития текста. Иногда уместно предполагать, что основа сравнения имеет языковую мотивированность, и тогда можно попробовать восстановить вероятный переход от одного образа к другому. В данном случае термин “орбита” отсылает к небесной обстановке стихотворения: если небо уподобляется катку, то бег конькобежцев по нему напоминает путь движения небесных тел. Вместе с тем этот термин означает также характерные пятна на шее кобры. Название

9 Ср. повторяющийся образ созвездий в сборнике “Близнец в тучах”, где быт постоянно противопоставляется поэзии, избранности и бессмертию художников. Ср. также образ неба, гадающего по линиям площади, как по ладони, в отрывке “Я спускался к Третьяковскому проезду. ..” (1910) [ПАСтеРнАК 2004, 3: 431]. О значимости темы линии в творчестве Пастернака говорит лейтмотив знака, который вдохновение оставляет на действительности. Этот знак может принимать вид герба (“Полярная швея”; “Баллада”), клейма (“Тоска, бешеная. . .”), тавра (“Как казначей. ..”), чекана (“Баллада”), печати (“Послесловье”). Все они наделены способностью придавать особую форму материи, оставляя на ней отличительный отпечаток.

10 Это поверье проявляется в многочисленных поговорках: ср. [АФАНАСьЕВ 1995, 1: 297]; ср. аналогичный по происхождению образ в стихотворении П. Вяземского “Первый снег”: “Цепями льдистыми покорный пруд окован. ...”.

11 Тема появляется уже в прозаическом отрывке “Диалог” (1917), где роль художников в идеальном обществе описывается как биржа жарообмена [ПАСТЕРНАК 2004, 3: 382]. Еще раньше, в письме родителям от 23 июля 1914 г., Пастернак называет художника “кочегаром культуры” [IDEM 2005, 7: 192]. Ср. также в “Охранной грамоте” определение главного стремления художника: “Цель же я видел всегда в пересадке изображения с холодных осей на горячие, в пуске отжитого вслед и в нагонку жизни” [IDEM 2004, 3: 160]. 
животного (очковая змея) вызывает следующее сравнение ночи с костью домино: в слове “очко” теперь актуализируется значение значка на костяшках ${ }^{12}$.

Итак, внешне непоследовательные образы обнаруживают глубинную языковую связность. На синтагматическом уровне проявляется только сходство: с одной стороны, звезды на ночном небе уподобляются светлым значкам на черных костях домино ${ }^{13}$; с другой же - сопоставление неба и катка обусловливает сходство следов бега по льду с орбитами светил и с пятнами очковой змеи. На глубинном уровне сравнения связаны и отчасти мотивированы лингвистически. Восстановление пропущенных звеньев не только облегчает понимание логической стройности строфы, но и доказывает изоморфизм мира и языка: структура текста призвана показать органическое соответствие подлинного строя действительности системе отношений в языке. Тема линии, являющаяся лейтмотивом предыдущих четверостиший, здесь принимает сначала форму орбиты, а потом - кости домино ${ }^{14}$. В процессе игры костяшки выстраиваются в причудливую линию, которая может напоминать рисунок того или иного созвездия ${ }^{15}$. К тому же эта игра по-новому подтверждаетсвязьискусствассудьбой,таккакявляласьраспространенным способом гадания ${ }^{16}$.

В четвертой строфе сравнение ртов бегающих конькобежцев с проглотившими “лаву льда” фальшивомонетчиками представляет собой новую вариацию на тему “жгучего мороза”. Образ объясняется тем, что в древней России фальшивомонетчиков казнили вливанием в рот расплавленное олово или свинец ${ }^{17}$. Это уподобление тоже затрагивает тему

12 Точнее, сближаются два отличных друг от друга слова: pluralia tantum “очки” и термин “очко” (мн. ч. “очки”) - значки на костяшках.

13 Домино тоже способно выражать зеркальность земли и неба, так как его кости бывают либо черного, либо белого цвета: в первом случае оно соответствует переполненному конькобежцами катку, во втором - усеянному звездами небу.

14 При переделке 1929 г. стих 11 превращается в “что как орбиты какой-то очковой”, где устраняется связь с коброй, но остается намек на очки. В версии 1957 г. образ меняется в корне. В новой форме “что как глаза со змеиным разрезом” возвращается змея, но сравнение касается не ее пятен, а разреза глаз. Выражение приобретает логичность, но утрачивает содержательность, потому что сохраняются одни визуальные элементы изображения в ущерб выше отмеченным семантическим признакам.

15 Благодарю Ф. Б. Успенского за это замечание.

16 Домино тесно связано с игрой в кости; некоторые исследователи даже считают, что оно является переложением разных комбинаций костей в гадательных целях.

17 Наказание предусмотрено в V главе Соборного Уложения 1649 г. Аналогичный образ появляется и в стихотворении О. Мандельштама “1 января 1924”: “Еще немного - оборвут / Простую песенку о глиняных обидах / И губы оловом зальют” (1924). [RoNEN 1983: 253] указывает, что образ расплавленного металла в виде напитка и казни встречается в футуристической поэзии, и в связи с этим 
творчества: “олово” отсылает к “слову” не только в силу паронимической аттракции, но и намеком на фразеологизм “слово - олово”, которым уверяют в надежности своего обещания ${ }^{18}$.

Более загадочным оказывается сравнение примерзшей к скобе луны с языком легавой. По мнению Б. Арутюновой, образ описывает мерцание луны на скобах коньков и опирается как на сходство их формы и блеска, так и на смежность конькобежцев со звездным небом. Исследовательница объясняет появление собаки уподоблением бега на коньках быстроте легавой: “Само сравнение с языком легавой может быть объяснено чисто физическим контрастом его влажности и тепла дыхания с холодом металла коньков: отражение месяца на скобе может к нему примерзнуть как язык легавой” [ARoutunovA 1979: 212]. Наряду с этим толкованием можно предположить, что собака отсылает к одноименным созвездиям, которые зимой можно видеть недалеко от Млечного Пути. Рядом с ними находятся также созвездия Ориона и Зайца, называющие мифического владельца самых легавых и их жертву. Хорошо знавший мифологию и астрологию Пастернак мог представлять себе серп луны у созвездия Пса как язык самого звездного животного. В таком случае луна, напоминающая одновременно по форме и скобу, и язык легавой, разделяется в образе языка собаки, лижущего скобу и от мороза прилипшего к ней. Пониманию этого образа способствует сопоставление с двумя сравнениями, имеющими аналогичную структуру:

$\begin{array}{llll}\text { воздух } & \text { железом } & \text { к ночи } & \text { прикован } \\ \text { месяц } & \text { языком обомлевшей легавой } & \text { к скобе } & \text { примерзает } \\ \text { рты } & \text { каку фальшивомонетчиков } & & \text { налиты лавой льда }\end{array}$

На основе трех сравнений лежит тема сковывающего мороза, которому противопоставляется жар, воплощенный и ковкой металла, и языком собаки, и дыханием конькобежцев. В последних двух образах передается также понятие сильнейшего переживания, не подлежащего словесному выражению. Итак, можно предполагать, что образ луны зрительно воплощает фразеологизм “язык прилипает (к гортани)”. С одной стороны, близость луны и созвездия Пса вызывает сравнение серпа луны с языком легавой; с другой же - тема невыразимых эмоций лирического переживания приводит к реализации вышеупомянутого выражения. В

перечисляет отдельные произведения В. Хлебникова (“Кавэ-кузнец”; “Опять чугунный кипяток. ..”) и Н. Асеева (“В стоны стали”), написанные позже этого стихотворения Пастернака.

18 Кроме О. Мандельштама, связь между этими словами обыгрывают В. Маяковский в том же 1924 г. (“Владимир Ильич Ленин”) и Б. Пастернак в стихотворении 1936 г. “Скромный дом, но рюмка рому. ..” [RONEN 1983: 254]. 
целом эти три сопоставления описывают пушкинский “холод вдохновения”, то есть несказанность поэтического вдохновения, которое всетаки просится на бумагу. Оксюморон жгучего мороза разрешается лирическим преображением действительности, где противоположности сливаются как при восторженной встрече катка с Млечным Путем.

\section{2. Образы катания на льду в творчестве Пастернака}

Смысл, вложенный Пастернаком в образ конькобежца, проясняется в письме родителям от 12/13 июля 1914 г.:

Искусство я представляю себе в виде какого-то векового вдохновения, которое мчится на одном коньке, скользя по душевным затонам отдельных избранных, и оставляя свой след на них, след одномерной, делимой только в одном направлении - в направлении историческом, - и не делимой никак иначе математической линии. Абсолютная оригинальность художника, его индивидуальность - это ведь сама неделимость того следа, который оставляет искусство, - если он отчерчен искусством, художник неделим, - как линия прохождения искусства - не иначе [ПАстЕРНАК 2005, 7: 186].

Если здесь линия как своего рода отпечаток искусства, отличающий художника от остальных людей, относится только к творчеству как таковому, то в стихотворении она является также формой произведения. Примечательно, что у Пастернака творческий процесс вообще связан с темой судьбы: само искусство предстает как гадание, где человек призван уловить сущность и верно передать ее. Такое представление четко выражается в стихотворении “Скромный дом, но рюмка рому. ... (1936): “Слитки рифм, как воск гадальный, / Каждый миг меняют вид. / От детей дыханье в спальной / Паром их благословит” 19 .

Установленная в письме связь между образами конькобежца и художника повторяется дважды в “Охранной грамоте” (1929-1931). Первый случай завершает часть автобиографии, посвященную итальянскому путешествию Пастернака 1911 г. В тексте пребывание в Венеции передается прежде всего как волнующее переживание отношений между художником, искусством и действительностью. В связи с этим кажется неслучайным, что описание венецианского эпизода обрамляется именно образами звездного потока и катания. Напомним первое впечатление писателя при выходе с вокзала: “. . . что-то плавное тихо скользнуло мне под ноги. . . тронутое двумя-тремя блестками звезд” [ПАстеРНАК 2004, 3: 198; здесь и далее курсив мой. - P. С.]. Во время следующего блуждания по ночному городу автор описывает, как

${ }^{19}$ Ср. также письмо Н. В. Завадской от 25 декабря 1913 г. [ПАСтеРнАК 2005, 7: 155], в котором Пастернак описывает творческий процесс, как разгадывание. О теме линии в ранней прозе Пастернака см. [ГоРелик 2000: 18-27]. 
В высоте поперек черных, как деготь, щелей [. . .] светлело ночное небо, и все куда-то уходило. Точно по всему Млечного пути тянул пух семенившегося одуванчика, и будто ради того лишь, чтобы пропустить колонну-другую этого движущегося света, расступались порою переулки, образуя площади и перекрестки [ПАСТЕРНАК 2004, 3: 200].

В конце пути прогулка уподобляется передвижению по небу: “. . . у меня сложилось такое чувство, будто я только что пересек расстояние, равное звездному небу Венеции, в направлении, встречному его движению” [ПАстернак 2004, 3: 201]. Наконец, пребывание в Венеции закрывается описанием оживленности площади Св. Марка во время вечернего спектакля: “Когда концерт кончился, стал слышен жернов равномерного шарканья, вращавшийся и раньше по галерейному кругу, но тогда заглушавшийся музыкой. Это было кольцо фланеров, шаги которых шумели и сливались, подобно шороху коньков в ледяной чашке катка" [IBID.: 208]. В другом отрывке так передается то ошеломляющее впечатление, которое Маяковский произвел на Пастернака при их первой встрече:

Он [...] хмурился, рос, ездил и выступал, и в глубине за всем этим, как за прямотою разбежавшегося конькобежиа, вечно мерещился какой-то предшествующий всем дням его день, когда был взят этот изумительный разгон, распрямлявший его так крупно и непринужденно. За его манерою держаться чудилось нечто подобное решенью, когда оно приведено в исполненье и следствия его уже не подлежат отмене. Таким решеньем была его гениальНОСТЬ [...] [ПАСТЕРНАК 2004, 3: 215-216].

Гениальность Маяковского противопоставляется описанной несколько раньше посредственности последнего русского императора, которому судьба отвела несоразмерную с его способностями роль в истории. Это противоречие выражается в контрасте между глаголами скользить и поскальзываться, которые этимологически родственны, но обозначают разное движение:

Что же делается с людьми этого страшного призванья, если они не Цезари, если опыт не перекипает у них политикой, если у них нет гениальности единственного, что освобождает от судьбы пожизненной в пользу посмертной? Тогда не скользят, а поскальзываются, не ныряют, а тонут, не живут, а вживаются в щекотливости, низводящие жизнь до орнаментального прозябаНьЯ [ПАСТЕРНАК 2004, 3: 211] ${ }^{20}$.

20 Об этом противоречии см. [ФЛЕЙШМАН 1979: 129-130, прим. 24; IDEM 2003: 337]. 


\section{3. Истоки связи между темой творчества и образом конькобежца}

Связь катания на льду с творчеством имеет вполне определенные литературные корни. В немецкой поэзии существует целая традиция, в которой катание на коньках не только является основным предметом изображения, но и прочно сочетается с поэтическим творчеством. Зачинателем этого направления является Фридрих Готлиб Клопшток (1724-1803). Хотя до него катание на льду уже нашло свое описание в немецкой литературе [LEE 1999: 194], именно Клопшток придал этой теме огромную популярность и особое значение, выходящее за рамки простого живописания. Этому зимнему спорту поэт посвятил пять стихотворений: “Der Eislauf” (1764), “Der Kamin” (1765), “Braga” (1766), “Die Kunst Tialfs" (1767), "Winterfreuden” (1797) ${ }^{21}$.

Для нашей темы особый интерес представляет “Der Eislauf”, где впервые устанавливается качественная однородность создания поэтического текста и катания, одинаково наделенных трансцендентальной сущностью. Именно такое восприятие катания кладет начало специфической традиции поэтического изображения этого спорта, который, благодаря личному опыту и лирическому примеру Клопштока, станет весьма популярным в немецкой литературной среде второй половины XVIII века ${ }^{22}$.

В тексте целый ряд намеков превращает катание в символ лирики: эти разные занятия объединяет и возможность преодолеть ограниченность человеческой жизни, достигая бессмертия, и присущая этой попытке опасность.

Тема смерти вообще обрамляет текст. В первой строфе гибель еще только метафорична, она предстает как “погребение в вечную ночь”, то есть как забвение, грозящее и самым блестящим достижениям человеческого духа: "Vergraben ist in ewige Nacht / Der Erfinder grosser Name zu

${ }^{21}$ В дальнейшем они будут обозначены так: "Der Eislauf” - [E]; “Der Kamin” [K]; "Braga" - [B]; "Die Kunst Tialfs" - [KT]; "Winterfreuden" - [W]. Тексты цитируются по изданию [КLOPSTOCк 2010].

22 См. свидетельство Гете в его автобиографии "Dichtung und Wahrheit" (ч. III, кн. 12). Назовем только несколько из этих авторов: J. W. Goethe (“Mut”, "Winter”); Novalis (“Der Eislauf”); J. G. Herder (“Der Eistanz”); K. W. Ramler (“Sehnsucht nach dem Winter”), H. Löns (“Immer langsam voran”); C. F. Meyer (“Die schlittschuhe”); August von Platen (“Auf Gewässer, welche ruhen. ..”); A. H. Hoffmann von Fallersleben ("Der Eislauf"); F. Rückert ("Die Schlittschuhläuferin”); F. C. Bindemann (“Der Eislauf”); G. Sander (“Lied auf dem Eise zu singen”); R. Schlösser ("Eiskunstläufer”), E. Geibel (“Sei mir gegrüßt, o klingender frost. .. ”). K этой традиции примыкает и Вордсворт в своей Прелюдии (W. Wordsworth, “The Prelude", кн. I, ст. 452-499) и вслед за ним английский поэт Edmund Blunden (“The Midnight Skaters"). Хочется упомянуть и современного канадского поэта P. Питерса (Robert Peters), который назвал один из своих сборников "The Poet as Ice-Skater" (1975). 
oft! / [ . . ] Wer nannte dir den kühneren Mann, / Der zuerst am Maste Segel erhob? / Ach verging selber der Ruhm dessen nicht, / Welcher dem Fuss Flügel erfand!” Примером незаслуженно забытых творцов являются создатели паруса и коньков. Сближение этих разных занятий предваряет образ поэта-конькобежца, так как морское плавание издавна служит метафорой опасности лирического путешествия [LEE 1980: 47] ${ }^{23}$. К тому же это сопоставление, в котором парус соотносится с коньками, а море - со льдом, лежит в основе описания катка как потока, которое становится лейтмотивом последующих стихов о катании: в дальнейшем у Клопштока ледяная поверхность названа "хрустальное озеро” или "хрустальная вода" (“des krystallnen Sees”, "der Woge von Krystall” [B]), “затвердевшая вода" или “затвердевший поток” (“das erstarrte Gewässer” [K]; "der stehend Strom” [KT]), или просто поток (“Strom” [B], [KT]). Таким образом, катку приписываются динамичность и потенциальная опасность морской пучины.

Тем не менее в начале текста подчеркиваются преимущественно те черты катания, которые сближают его с поэзией. Описывая коньки как “крылья для ног” и “водяные котурны”, Клопшток наделяет их способностью временно преодолевать прикованность человека к земле и открывать доступ к высшей реальности. Катание позволяет испытывать полноту жизни: оно дарит восторг и здоровье, обостряет чувства, даже дает возможность предчувствовать то, что еще невидимо ${ }^{24}$. Примечательно, что это занятие разворачивается в особое время, ночью: ночь с одной стороны является символом забвения (“ewige” Nacht), с другой же - представляет собой самое подходящее время для катания, то есть поэтическую пору, когда действительность преображается, раскрывая свою подлинную сущность. Вообще образ катания построен на оппозиции: с одной стороны, он противопоставляется обыденному быту городскому уюту и дню, с другой же - его характеризует контраст между тишиной полей и звуком коньков, скользящих по льду. Этот скрип как будто оживляет природу и издалека предвещает присутствие конькобежцев. Наконец, катание объявляется верным источником славы для самого Клопштока, изобретшего “танец для скользящей стали”, то

23 Одинаковым образом Пастернак в своей переписке описывает порыв вдохновения образом “отчаливания” [ПАСтЕРнАК 2005, 7: 41]; метафоры “мачта лиризма” [IBID.: 151] и “мачта гениальности” [IDEM 2004, 3: 161] передают его понятие поэзии, и “порванные снасти” [IBID.: 436, 444, 481, 502] обозначают начало лирического пути. Этот набор образов пронизывает также стихотворение “Лирический простор” (1913).

${ }^{24}$ Все это передается конкретными образами: "Und sollte der unsterblich nicht seyn, / Der Gesundheit uns und Freuden erfand, / Die das Ross muthig im Lauf niemals gab, / Welche der Reihn selber nicht hat? / [ . . ] Fern verräth deines Kothurns Schall dich mir, / Wenn du dem Blick, Flüchtling, enteilst [...] / Winterluft reizt die Begier nach dem Mahl; / Flügel am Fuss reizen sie mehr!" 
есть сумевшего не только изобразить, но и ритмом передать всю прелесть катания ${ }^{25}$. Знаменательно, что катание и посвященная ему поэзия оказываются тождественными: Клопшток сначала гордо напоминает свой “танец” в стихах, а потом излагает свои взгляды на то, какие движения отличают настоящего мастера катания. При этом образцом для подражания спортивному совершенству является именно художник, в частности - рисовальщик И. М. Прейслер ${ }^{26}$ : “Künstle nicht! Stellung, wie die, lieb’ ich nicht, / Zeichnet dir auch Preisler nicht nach.” Отсылка к авторитету Прейслера подчеркивает внутреннюю связь катания с искусством и важную роль оригинальности в творчестве 27.

Во второй половине стихотворения светлая картина катания резко омрачается. Мы уже видели, что ночь, идеальное поэтическое время, является одновременно и метафорой вечного забвения. Звуки на катке также неоднозначны: если скрежет коньков предвещает приближение еще невидимых конькобежцев, то иногда слышно "Wie der Todeston wehklagt auf der Flut”, когда лед внезапно раскололся. “Хрустальная равнина” манит человека (“des Krystalls Ebne dir winkt”), но ее привлекательность может обернуться трагедией: “Denn wo dort Tiefen sie deckt, strömts vielleicht, / Sprudeln vielleicht Quellen empor. / Den ungehörten Wogen entströmt, / Dem geheimen Quell entrieselt der Tod!” Предлагая уникальный экзистенциальный опыт, чреватый или вдохновением, или фатальным исходом, каток является моделью непредсказуемости жизни. Во время катания конькобежец будто преодолевает силу тяжести, но это ощущение может оказаться призрачным, ведь он такой же легкий, но и такой же хрупкий, как листок в воздухе: "Glittst du auch leicht, wie diess Laub, ach dorthin; / Sänkest du doch, Jüngling, und stürbst!” Итак, в конце текста начальная метафора забвения как "вечного погребения” превращается в настоящую гибель, окрашивая стихотворение новым, более трагическим значением.

В следующих стихотворениях о катании на коньках эта картина обрастает новыми подробностями, но существенно не меняется. Описанный пейзаж остается прежним, равно как и стержневая роль в тексте оппозиций день/ночь и быт/катание. Появление луны отмечает переход от обычной обстановки к поэтической: катание производится ночью

25 Именно “Der Eislauf” считается блестящим примером ритмического подражания походки по льду в стихах: см. [THAYER 1981: 33].

${ }^{26}$ J. M. Preisler (1715-1794) немецкий гравер, профессор Датской Королевской Академии изящных искусств и личный друг Клопштока.

27 Значение оригинальности еще ярче выражается в стихотворении “Die Kunst Tialfs”, где Клопшток восхваляет опыт первого прохода по еще нетронутому катку: "O Bahn des Krystalls! Eh sie dem Schlittner den Stachel reicht, / Eh sie durch Schärfung den Huf, durch den Eissporn den Wanderer / Sichert, erstarr, erstarr an der Esse die Amboshand!" 
или рано утром, когда иней отражает первый свет; мягко сверкающие поля погружены в тишину, прерываемую лишь звуком коньков ${ }^{28}$. Коньки снова описаны как крылья и водяные котурны ${ }^{29}$. Бег по льду неизменно вызывает радостное ощущение полного здоровья, вдохновляет и дарит освежающую теплоту ${ }^{30}$. Мы уже видели, что каток постоянно изображается как поток, приобретая характерные для воды динамичность и опасную непредсказуемость. В описании ледяной поверхности получает также развитие зеркальность земли и неба: если в “Der Eislauf” лед просто сопоставлялся со звездами, а в “Braga” уже появились “звезды хрустального озера”, которые могли относиться так к небу, как к блистающему катку, в стихотворении “Die Kunst Tialfs” лед назван "звездным хрусталем” и вообще “потоком” 1 . Итак, с одной стороны звездное небо как будто переносится на землю, с другой - лед сохраняет свое изначальное жидкое состояние. У Пастернака это отношение повторяется, но в перевернутом виде: не звезды спускаются на землю, а каток

28 "Sein Licht hat er in Düfte gehüllt, / Wie erhellt des Winters werdender Tag / Sanft den See! Glänzenden Reif, Sternen gleich, / Streute die Nacht über ihn aus! // Wie schweigt um uns das weisse Gefild! / Wie ertönt vom jungen Froste die Bahn! / Fern verräth deines Kothurns Schall dich mir..." [E]; "Welche Tage gabest du mir! wie begannen sie, wenn sich / In der Frühe Glanz färbte noch bleibender Reif; / Welche Nächte, wenn nun der Mond mit der Heitre des Himmels, / Um der Schönheit Preis, siegend stritt, und besiegt” [W]; "der Jüngling [. . . / Blickt er umher, und sieht, / Wie der Wecker mit dem röthlichen Fuss / Halb im Gewölke steht, / Und der Winter um sich her das Gefilde / Sanft schimmernd bedeckt, und schweigt. [...] Wenn am Abend / Rauschender Winterkohl / Sie geletzt hat, so verlassen sie schnell / Die sinkende Glut des Heerds, / Und beseelen sich die Ferse, die Ruh / Der schimmernden Mitternacht" [K]; "Wecket dich der silberne Reif / Des Decembers, o du Zärtling! nicht auf? / [...] Der December hat noch nie so schön, / Nie so sanft, wie heut, über dem Gefilde gestrahlt! / Und die Blume von dem nächtlichen Frost Blühte noch niemals, wenn es tagte, so! [... ] Schwebete den Tanz des Bardiets / In dem schimmernden Gedüfte" [B]; "Wie das Eis hallt! Töne nicht vor! ich dulde es nicht! / Wie der Nacht Hauch glänzt auf dem stehenden Strom! [. . . In dem hellen Dufte des schönsten der Dezembermorgen [. ..] Wer sind sie, die daher in dem weissen Dufte schweben? [. . .] Nur Ein Gesetz: Wir verlassen nicht eh den Strom, / Bis der Mond an dem Himmel sinkt! / [ . . ] Wie glatt ist der schimmernde Frost!" [KT].

29 "Und beflügelt sich mit Stahle den Fuss [. . .] Jetzt legt auch die Beflüglung des Stahls" [K]; "Darf nie wieder am Fuss schwingen die Flügel des Stahls? / Wasserkothurn. .." [W]; “Über der Woge von Krystall erfand / Diese Beflüglungen des Stahles” [B]; "Und dem Jüngling horcht, der hinter ihr / Den Stahlen der ruhenden Flügel giebt?” [KT] (здесь речь идет, однако, не о коньках, а о полозьях).

${ }^{30}$ Cp.: “. . . von dem Gefühle der gesundheit froh” [B]; "Mit Gefühle der Gesundheit durchströmt / Die frohe Bewegung sie, / Da die Kühlungen der reineren Luft / Ihr eilendes Blut durchwehn, [... ] Unermüdet von dem flüchtigen Tanze" [K]; "Der du so oft mit der labenden Glut der gefühlten Gesundheit / Mich durchströmetest, Quell längeres Lebens mir warst" [W], см. также "Gesundheit [...] und Freuden [...] / Welche der Reihn selber nicht hat? [. . . Winterluft reizt die Begier nach dem Mahl; / Flügel am Fuss reizen sie mehr!” [E].

${ }^{31}$ Cp.: "Glänzenden Reif, Sternen gleich" [E]; "die Gestirne des krystallnen Sees" [B]; "Sternkrystall”, "bestirntem Krystall”, "Stehenden Strom”, "Strom” [KT]; ср. также “im Laufe zum besternten Landsee" [K]. 
поднимается на небо, которому, в свою очередь, предписывается жидкое состояние “звездного потока”. К тому же катание на льду сочетается также с образами охоты и пира: коньки звенят, как весеннее пение охотников ("Wie des Jägers Lenzgesang aus der Kluft zurüch, / Tönt unter ihrem Tanze der Krystall!”) 32, а конькобежцы подкрепляют себя вином: “Du Schweber mit der blinkenden Schale dort: / Den der Winzer des Rheins kelterte, / Den! und die Schale voll bis zum Rand' herauf! / Im Fluge geschwebt! doch kein Tropfen fall' auf den Strom!” $[\mathrm{KT}]^{33}$.

Связь поэзии с катанием подчеркивается отсылкой к норвежской мифологии. B “Braga” внушенному ночным катанием лирическому преображению действительности соответствует появление в лесу Браги, северного бога поэзии и катания ${ }^{34}$. Тот же мифический пласт появляется у Клопштока год спустя в стихотворении “Die Kunst Tialfs”35, в котором представлен диалог трех бардов. К тому же этот текст содержит многочисленные намеки на функциональную схожесть катания на коньках и лирического вдохновения. Например, извилистый ход конькобежцев поэт уподобляет мышлению, таким образом подчеркивая с одной стороны молниеносность поэтических ассоциаций, с другой же - ведущую роль ритма в стихотворчестве ${ }^{36}$.

32 Cр. также “Winterfreuden”, ст. 13. Эти темы уже кратко появились в стихотворении “Der Eislauf”, где упоминаются звуки рогов, подразумевая, видимо, музыкальные инструменты охотников; в тексте описывается также изобилие еды, призванной утолить возбужденный катанием голод конькобежцев. Эти образы найдут отражение и в следующей традиции стихов о катании, см. например “The Prelude” Вордсворта: "We hissed along the polished ice in games / Confederate, imitative of the chase / And woodland pleasures, the resounding horn, / The pack loud bellowing, and the hunted hare."

${ }^{33}$ Ср. также: "Wir haben doch zum Schmause genung / Von des Hahnes Frucht? und Freuden des Weins?” [E]; "blinkete heller der Wein” [W]; "O wie trunken von den Mimer! Ich sah / Fern in den Schatten an dem Dichterhain” [B].

34 В другом произведении, “Wingolf” (1767), Клопшток указывает не на Браги, а на Улля как на мастера катания. Эта последняя версия больше соответствует норвежской мифологии, где Браги прославляется красноречием и искусством плетения слов, в то время как Улль известен как отменный стрелок, конькобежец и лыжник (см. [SIMEK 1996: 42-43, 339]). О том, как своеобразно Клопшток обращался с норвежской мифологией см. [STRICH 1970: гл. 1, § 4; BROWNING 1978 : 252-254].

35 Эту оду, впервые опубликованную в 1771 г. под названием “Eisode”, пересказывает и хвалит Мадам де Сталь в книге “De l’Allemagne” (гл. “De la poésie allemande”).

36 "Schnell wie der Gedanke, schweben sie in weitauskreisenden Wendungen fort, / Wie im Meere die Riesenschlange sich wälzt”: сравнение быстроты катания с молниеносностью мысли и упоминание змеи отсылают к изложенному в Младшей Эдде случаю, когда Тор и его сподвижники тщетно стараются превзойти Локи. В частности, сначала Тьяльф состязается в беге с помощником Локи по имени Хуги ('мысль'), а потом сам Тор с трудом поднимает кота, который на самом деле оказывается змеей Мидгардом, кольцами тела обнимающей мир. Возможно, что, наряду с вышесказанным, образ очковой змеи у Пастернака навеян и этим мифическим фоном стихов Клопштока. 
Несколько раньше Клопшток воспевает радость хождения по нетронутому льду, что явно коррелирует с его поклонением оригинальности писателя, с восприятием творчества как пути в неизвестность. Эта установка у Клопштока находит самое верное подтверждение в изобразительном искусстве: как в “Der Eislauf” искусственная поза конькобежца подвергалась критике и объявлялась недостойной мастерства Прейслера, так же и в стихотворении “Der Kamin” напоминается, что любой подлинный мастер рисования неестественности платного натурщика предпочитает непринужденность непрофессиональной модели ${ }^{37}$. В связи с этим, наряду с положительными качествами катания, снова появляются и его губительные черты, которые в этот раз отражаются в личном опыте поэта: в “Winterfreuden” Клопшток вспоминает случай на озере Лингби, когда поэт чуть не утонул из-за внезапно расколовшегося льда.

Таким образом можно сказать, что этими произведениями Клопшток дал новое осмысление катанию на коньках, которое оказывается вовсе не развлечением, а продолжением поэтической деятельности в другой форме ${ }^{38}$. При этом сама поэзия предстает как глубочайшее жизненное испытание, где для достижения бессмертия человек призван обнажать свою суть, подвергаясь риску полного провала. Итак, по меткому замечанию Альберт, катание на коньках “als Modell der Dichtung die poetologischen Grundfragen des 18. Jahrunderts thematisiert: das Verhältnis von Antike und Moderne, von Autorität und Originalität, die Bestimmung der Dichtung als «Malerei» oder «Darstellung von Empfindung» und schließlich die Nähe von schöpferischem Selbstgefühl und Tod” [ALBERT 1994: 82].

\section{4. Пастернак и Клопшток}

У нас нет сведений, подтверждающих знакомство Пастернака с поэзией Клопштока вообще и с этими стихотворениями в частности. Насколько мы знаем, немецкий поэт не упоминается ни в произведениях, ни в письмах Пастернака. К тому же известные нам исследования о связи творчества Пастернака с немецкой культурой не выявили каких-либо

\footnotetext{
Оды Клопштока о катании могли отражаться в произведении Пастернака и на языковом уровне: появление орбиты у Пастернака может быть мотивировано еще и тем, что в немецком языке Bahn означает одновременно и каток (Eisbahn), и орбиту небесных тел.

37 "Die gesünderen, und froheren wünschet / Der kennende Zeichner sich, / Und vertauschte das gelohnte Modell / Gern mit dem freyeren” [K]; ср. также "Dann war leichter der Schwung, und die Stellung unkünstlicher" [WF].

38 Клопшток демонстративно подчеркивал это осмысление и в повседневной жизни: когда молодые поэты пытались поговорить с ним о литературе, он непременно переходил на тему мастерства конькобежного катания (см. Гете, "Dichtung und Wahrheit», ч. III, кн. 15: [GoETHE 1985: 696-697]).
} 
следов чтения Клопштока [EvANS-RoMAINE 1997; NöLDEKE 1986; SHEIKHOLESLAMI 1985]. Все же это предположение остается вполне вероятным, учитывая глубокое знание Пастернаком немецкого языка и культуры. В юности поэт дважды достаточно долго бывал в Германии: сначала вся его семья прожила семь месяцев в Берлине в 1906 г., а потом он один провел в Марбургском университете летний семестр 1911 г. В своих воспоминаниях А. ПАстЕРНАК [2002: 259] утверждает, что во время первого совместного пребывания в Берлине “брат начал увлекаться чтением немецких классиков - стихов главным образом”: возможно, именно к этому периоду и относится знакомство Пастернака с интересующими нас произведениями Клопштока.

В частности, внимание к одам немецкого поэта могло вызвать в нем то место гетевской автобиографии “Dichtung und Wahrheit”, где писатель изображает увлечение ночным катанием, внушенное ему Клопштоком. Здесь Гете описывает внутреннее единство природы, стихов и вдохновения, которые плавно переходят друг в друга: впечатления от ночного катания напоминают оссиановскую атмосферу и вызывают в памяти соответствующие стихи Клопштока; этот восхитительный опыт, в свою очередь, вдохновляет молодого Гете к созданию новых произведений ${ }^{39}$. Клопшток упоминается также в романе "Die Leiden des jungen Werther”. В известном эпизоде Шарлотта, любуясь красотой природы после дождя, передает свой восторг Вертеру простым восклицанием “Клопшток!”, что является верным намеком на его популярнейшую оду "Frühlingsfeyer"40. К тому же, хотя Гете довольно быстро затмил Клопштока ${ }^{41}$, седьмая строфа стихотворения "Der Eislauf” считается одной из вершин немецкой лирики [THAYER 1981: 34], так что вряд ли этот текст остался вне круга чтения Пастернака. Наконец, поскольку многие известные композиторы создавали музыкальные переложения стихов

39 И. Гете, “Dichtung und Wahrheit”, ч. III, кн. 2: [GoEthe 1985: 557-558]. У Гете катание на льду появляется также в романе "Wilhelm Meisters Wanderjahre”, в сцене ночной прогулки на коньках, где каток определяется как "eine glatte, dem Geschickten, dem Kühnen geöffnete Fläche verbunden” (кн. II, гл. V: [GoETHE 1970: 177]).

40 Уже в начале XIX века в России Клопшток стал настолько малоизвестным, что один из переводчиков романа Гете воспринял его фамилию как опечатку в слове “клапштос” (особый удар кием в игре на бильярде), и соответственно исказил русский текст [ВязЕмский 1929: 253-254].

41 Еще в позднем периоде его творчества во всей Европе Клоштока скорее уважали как автора поэмы “Der Messias”, чем читали на самом деле [THAYER 1980: 358-359]. Гете перенял у него много тем и образов, подавая их в новом виде. Огромный успех его произведений заслонил имя Клопштока и скрыл эту преемственную связь: см. [LEE 1999]. О быстро прошедшей славе Клопштока см. эпиграмму Лессинга: "Wer wird nicht einen Klopstock loben? / Doch wird ihn jeder lesen? - Nein. / Wir wollen weniger erhoben / Und fleißiger gelesen seyn” (цит. в [THAYER 1973: 207]). 
Клопштока ${ }^{42}$, маловероятно, что имя немецкого поэта могло остаться незамеченным молодым Пастернаком, готовящимся к музыкальной карьере.

“Конькобежный цикл” Клопштока содержит в себе много тем, перекликающихся с жизненным опытом и эстетическими размышлениями молодого Пастернака. Оба поэта устанавливают существенную связь между творчеством и испытанным ими риском внезапной гибели. Мы видели, что у Клопштока представление катания на льду как угрожающей фатальными последствиями деятельности генетически отсылает к случаю на озере Лингби, где, как рассказывается в стихотворении “Winterfreuden”, немецкий поэт чуть не утонул, провалившись во внезапно расколовшийся лед ${ }^{43}$. Образ грозных волн у него связан также с кораблекрушением, пережитым во время путешествия из Гамбурга в Копенгаген в 1756 г. [KLOPSTOcK 1988: 45-48]. Пастернак тоже многократно ощущал близость смерти летом 1903 г., когда ряд трагических случаев оставил неизгладимый след в его душе: многократные попытки самоубийства одной молодой девушки и гибель спасавшего ее студента, падение с лошади самого будущего поэта, после которого он стал хромать, а его отец, художник Л. Пастернак, прекратил работу над картиной, изображающей ту ночную скачку. По меткому замечанию О. РАЕВской-Хьюз [1994: 147], “многообразный опыт смерти лета 1903 г. действительной смерти «ближнего», собственного «падения-поражения» и «разрыва» в творческой биографии отца - был также и опытом начала творчества и бессмертия. [. . .] Бессмертие, связанное в дальнейшем с преображением, было осознанно в первую очередь именно как творческое бессмертие"44. Итак, для обоих поэтов творчество является экзистенциальной деятельностью, где каждый раз подвергается испытанию достоинство художника.

${ }^{42}$ Напр. Шуберт (“An sie”; “Nun laßt uns den Leib begraben”; "Furcht der Geliebten”; "Das große Halleluja”; "Das Rosenband”; "Dem Unendlichen”; "Die frühen Gräber”; "Die Gestirne”; “Edone”), Малер (“Aufersteh’n, ja aufersteh’n wirst du”) Р. Штраус (“Das Rosenband”); Глюк (“Der Jüngling”; “Die frühen Gräber”; “Die Neigung”; “Die Sommernach").

43 "Ach einst wurdest du mir, Kothurn, zum tragischen! führtest / Mich auf jüngeres Eis, welches dem eilenden brach. Bleich stand da der Gefährt; mein Schutzgeist gab mir Entschluss ein; / Jener bebte nicht mehr; und die Errettung gelang. / Als sie noch schwankend schien, da rührte mich innig des Himmels / Lichtere Bläue, vielleicht bald nun die letzte für mich! / Dank dir noch Einmal, Beindorf, dass du mich rettetest!"

44 Вот как в дальнейшем Пастернак опишет значение этого события для своей жизни: “Мне жалко 13-летнего мальчика с его катастрофой 6 августа. Вот как сейчас лежит он в свежей незатвердевшей гипсовой повязке, и через его бред проносятся трехдольные, синкопированные ритмы галопа и падения. Отныне ритм будет событием для него, и наоборот, события станут ритмами; мелодия же, тональность и гармония - обстановкою и веществом события" [ПАСТЕРНАК 2004, 5: 319]. См. также [Горелик 2000: 14-16]. 
Добавим, что Клопшток и Пастернак одинаково ассоциируют творческий процесс с рисованием, указывая на естественность самовыражения как на верный залог подлинности в искусстве. Мы видели, что немецкий поэт, объясняя своему товарищу, как надо кататься на льду, подчеркивает, что в рисунке, как и в движениях искусного конькобежца, осуждается прежде всего наигранность, и апеллирует к авторитету гравера И. М. Прейслера ${ }^{45}$. По мысли Клопштока, движения конькобежцев должны подражать естественности линий рисунка, и тогда катание превращается из простого вида спорта в настоящее искусство. В свою очередь такое рафинированное движение достойно стать источником художественного вдохновения: "Ist die Stellung nur richtig, kann der gute Eisläufer umgekehrt dem «kennende[n] Zeichner» Modell stehen; «gesünder», «froher» und «freyer» als «das gelohnte Modell», wird er dem bildenden Künstler zu einer newuen Inkarnation idealer Schönheit" [HıLLIARD 1989: 150]. Итак, линии рисунка и следы коньков оказываются эквивалентными ${ }^{46}$; при этом отсылка к другому виду искусства обеспечивает ту возможность соперничества, а не слепого подражания, которая, по мнению Клопштока, лежит в основе настоящего искусства ${ }^{47}$. Пастернак тоже считал непринужденность самовыражения непременным зародышем оригинальности ${ }^{48}$ и связывал ее с образом линии. В его ранней неоконченной статье в защиту искусства Л. Пастернака ${ }^{49}$ стилизация осуждается как установка на форму, а не на содержание: по мнению писателя, настоящее искусство не подражает уже устоявшему стилю, а черпает вдохновение у самой природы. В этом смысле творчество соответствует рисованию с натуры: линия наброска моделирует способность настоящей художественной формы синтезировать одним штрихом разнообразие и переменчивость действительности. Поэт следующим образом описал принцип работы своего отца:

45 Среди изобразительных искусств Клопшток особенно ценил гравюру, потому что возможность бесконечного воспроизведения рисунка обеспечивает долговечность художнику и его изделию [THAYER 1973: 190]. Тем не менее писатель отдавал абсолютное преимущество литературе, чья словесная природа позволяет действовать одновременно и на эмоциональном, и на умственном yровнях. Об этой теме см. [HILLIARD 1987: § 6; THAYER 1980: 337-339].

${ }^{46}$ Именно в этом соответствии исследователи обнаруживали связь описания извилистого движения конькобежцев у Клопштока с известной теорией змеевидной линии красоты, предложенной В. Хогартом (W. Hogarth): cм. [HILLIARD 1989: 151; BEDENK 2004: 133-138].

47 О связи этого представления Клопштока с переосмыслением понятия оригинальности в XVIII в. вообще и с произведением Э. Янга (Е. Young) "Conjectures on Original Composition" (1759) в частности, см. [LEe 1999: 50-51].

${ }^{48}$ Ср., например: [ПАСтеРНАК 2005, 7: 94-95, 138, 646; IDEM 2004, 5: 57].

49 Вероятно, статья должна была служить ответом на выпады, адресованные весной 1910 г. А. Бенуа Л. Пастернаку в рамках критики деятельности Союза русских художников. 
он один [...] пошел от вероятного родника формы, от линии, рассчитанной на цельность и непрерывность, [. . .] линии, твердо знающей, что рука, ведущая ее, воссоздаст живую кровеносную ткань природы, не осекаясь ни на чем и в срок достаточно мгновенный для того, чтобы живая кровь, как в натуре, не обогнала ее и не оставила ее позади <сего>, обреченного на удел атрофированной линии. . . [ПАСТЕРНАК 2004, 5: 286-287] ${ }^{50}$.

Эта общая установка на непосредственность выражения приводит обоих поэтов к высоко эмоциональной поэзии, где предельно вещественное описание действительности построено на внезапных тематических переходах. Итак, стихи Клопштока и раннего Пастернака производят впечатление пиндарического парения, когда только лирический восторг, пронизывающий действительность, связывает далекие друг от друга образы. Любопытно, что писатели одинаково находят аналогию этой ведущей роли переживания на композиционном уровне в древнегреческих дифирамбах ${ }^{51}$. Наконец, тема несказанности поэтического вдохновения, выраженная в конце пастернаковских стихов о катании, проявляется также в творчестве Клопштока: по мнению К. Альберт [ALBERT 1994], отождествление поэзии с катанием допускает и толкование возможной гибели как неспособности художника найти в самом себе словесное воплощение божественного духа.

\section{5. "Цельною льдиной. . ." и цикл Клопштока о катании}

Идейная близость Пастернака и Клопштока обусловливает многочисленные переклички стихотворения “Цельною льдиной. . .” с циклом Клопштока о катании. У немецкого поэта Пастернак заимствовал образ поэта-конькобежца, некоторые основные темы и отдельные штрихи. Мы видели, как оба поэта считали творчество экзистенциальным опытом,

50 Любопытно, что именно во время берлинского пребывания 1906 г. Л. Пастернак Занимался офортом [ПАСТЕРНАК Е. 1997: 77; ПАСТЕРНАК Л. 1975: 100]. Вообще отец поэта очень любил эту технику изображения и, хотя ему не пришлось много заниматься ей, всячески старался развивать в Москве все виды графического искусства [IBID.: 28, 138-140, 228]. О связи поэзии Б. Пастернака с творчеством его отца см. [SALYS 1992].

51 По мнению БухштАБА [2000: 293] сочетание лаконичной загадочности и обостренного лиризма у Пастернака напоминает греческий дифирамб и оду периода классицизма. Любопытно, что уже в 1917 г., говоря о цикле “Поверх барьеров”, К. Г. Локс отметил “дифирамбизм” Пастернака, который и одобрил это определение [ПАстЕРнАК 2005, 7: 314]. Клопшток определенно провозглашает дифирамбическую сущность своей поэзии в первой версии стихотворения "Die Kunst Tialfs": "The poetry that is sung and the dance that is skated are united as single action by [.. .] an action identified with the enthusiasms of dithyrambic poetry, represented in the ode both by the patronage of the god Braga and by Pindar, who in the first version of the poem is specifically named: «Sie tanzten fort, Strophen und Antistrophen, / Ruhten selten Epoden aus. / Sie tanzten den ganzen Pindar durch»” [LEE 1999: 196] (ср. также [ALBERT 1994: 82; BROWNING 1978: 197-214]). 
линию - воплощением моделирующей функции искусства, а поэзию возможностью передать “диво на земле” 52 , т. е. восторг перед жизнью в конкретных, осязаемых формах. В частности, они сходятся и в представлении о физической трансцендентности: у Пастернака тоже зеркальность Земли и Неба как преодоление их оппозиции ${ }^{33}$ осуществляется не через отталкивание от предметного мира, а через обостренность чувственного восприятия, которое позволяет временно переживать полноту вечности. Вообще Пастернак по-новому воспроизводит многие подробности клопштоковского цикла: ночная обстановка, луна, дымка, образ затвердевшего потока, тема вина, подкрепляющее силы и скрепляющее дружбу, контраст между тишиной и звуком коньков, и между холодом льда и теплом катания, отождествление катка со звездным небом, отсылки к теме охоты ${ }^{54}$. Наконец, на языковом уровне термины Bahn и Riesenschlange у Клопштока, возможно, отражаются в образе “орбиты змеи очковой” у Пастернака ${ }^{55}$. Эти соответствия наглядно доказывают, что одним из источников пастернаковского стихотворения являются перечисленные оды Клопштока. Мы показали, что существует богатая традиция стихов о катании на коньках, чьи авторы быстро превзошли в популярности ее основателя. Среди этих произведений стихи Гете и Гердера тоже оказываются близкими Пастернаку. Тем не менее, как нам кажется, эти совпадения обусловлены скорее всего общей отсылкой к Клопштоку ${ }^{56}$, и могут дополнять, но не опровергать связь

52 Ср. письмо К. Г. Локсу от 27 января 1917 г. “. . . нет того дива на земле, перед которым стало бы в тупик диво человеческого восприятия; надо только, чтобы это диво было на земле, то есть в форме в своей указывало на начало своей жизненности и на приспособленность своего сожития со всей прочей жизнью” [ПАСТЕРНАК 2005, 7: 314].

53 Об отношении земли и неба у Клоштока ср. следующее описание стихотворения "Der Eislauf": "The poet evokes a moment at which the diffused light of the still arriving day is punctuated («Sternen gleich») by the legacy of the night («Mond» [...]) just left. [...] with the common margin of landscape and sky obscured by luminous mist, and the lake at once bathed in soft light and sparkling radiantly, a single simile seems almost to erase the distinction between earth and heaven itself [...] The light, silence, and rushing but harmonious motion of «Der Eislauf» combine to make it the earthly approssimation in Klopstock's poetry of the celestial expanses with which it is made to seem, through description and rethorical figuration, almost continuous [...] «Der Eislauf» is unique [. . . in its representation of momentary physical trascendence" [THAYER 1981: 39-40].

54 О проявлении перечисленных тем в одах Клопштока о катании см. выше, прим. $30,32,33,34$.

55 См. выше, прим. 37. Термин Bahn часто появляется в цикле Клопштока о катании: "Wie ertönt vom jungen Froste die Bahn! [. . . Zurück! lass nicht die schimmernde Bahn / Dich verführen, weg vom Ufer zu gehn!” [E]; “der Bahn warnende Stimme vernahm” [W]; "scholl schnelleres Getöne der Bahn!” [B]; “O Bahn des Krystalls!" [KT].

56 Гете и Гердер придают катанию более общий экзистенциальный смысл, следуя в этом не только Клоштоку, но и его предшественнику Брокесу: см. [LEE 1999: 194, 
стихов Пастернака с циклом Клопштока, которая не сводится к лексическим перекличкам, а затрагивает и смысловой пласт произведения.

При этом нельзя не отметить, что Пастернак своеобразно перестраивает все эти идейные, тематические и образные переклички. Он вводит тему перевернутости творческого видения и по-новому развивает образ линии, которая становится также знаком судьбы художника, объединяя изображенную действительность, произведение искусства и его создателя. К тому же у Пастернака творчество так органично срастается с представленной картиной, что эта тема с трудом улавливается при первом чтении: на него намекают лишь зеркальность земли и неба и аллюзии на книгу Бытия. Яркость описанного мира усиливается тем, что Пастернак систематически развертывает и опредмечивает образы Клопштока. Таким образом внимание переходит от создателя к его произведению: назидательность Клопштока исчезает, и поэт уже не наставляет неопытного товарища, а сам сливается с преображенным миром так же, как луна превращается одновременно в скобу и в лижущий ее язык легавой.

В заключение заметим, что образ конькобежца появляется также в цикле О. Мандельштама на смерть А. Белого ${ }^{57}$. В стихотворении "Голубые глаза, и горячая лобная кость” одно из определений недавно скончавшегося поэта звучит так: “Конькобежец и первенец, веком гонимый взашей / Под морозную пыль образуемых вновь падежей”; в следующем за ним стихотворении "10 января 1934”58 образ повторяется: “Где прямизна речей / Запутанных, как честные зигзаги / У конькобежца в пламень

прим. 19]. Гете перенимает у Клопштока связь катания со смертью, расширяя ее значение от индивидуального до общечеловеческого плана: в стихотворении “Winter” каток представляет собой превратность жизненного пути (“Nur die Fläche bestimmt die kreisenden Bahnen des Lebens / Ist sie glatt, so vergißt jeder die nahe Gefahr”), а таяние льдов и приток воды к морю явно намекает на смену поколений (“Dieses Geschlecht ist hinweg, zerstreut die bunte Gesellschaft [...] / Schwimme, du mächtige Scholle, nur hin! und kommst du als Scholle / Nicht hinunter, du kommst doch wohl als Tropfen ins Meer”). “Der Eistanz” Гердера на словесном уровне оказывается ближе и Клопштоку, и Пастернаку: “Da stand sie, die Sonne, in Düfte gehüllt, / Da rauchen die Berge, da schwebet ihr Bild, / Da ging sie danieder, und siehe, der Mond, / Wie silbern er über und unter uns wohnt! [. . . Seht auf nun, da brennen im himmlischen Meer / Die Funken und brennen im Frost um uns her. [. . .] Wir gleiten, o Brüder, mit fröhlichem Sinn / Auf Sternengefilden das Leben dahin. [... . Er macht' uns geräumig den luftigen Saal / Und gab uns in Nöthen die Füße von Stahl / Und gab uns im Froste das wärmende Herz."

57 Об этом цикле вообще см. [СПивАК 2008А; ЕADEм 2008Б; ПоляковА 1992].

58 У этого текста нет устоявшегося названия: в собрании сочинений Мандельштама в трех томах [МАндельштАм 2009, 1: 192] стихотворение называется "Утро 10 января 1934 года”, в издании из серии “Библиотека поэта” [IDEM 1978: 172] оно дается вообще без названия. 
голубой, - Морозный пух в железной крутят тяге, с голуботвердой чокаясь рекой”. Примечательно, что в обоих случаях фигура конькобежца связана с речевым творчеством. На такую образную перекличку между стихами Пастернака и Мандельштама в свое время указали Л. ФлЕйшмАн [1979: 130, прим. 24] и О. Ронен ${ }^{59}$. Можно предполагать, что Мандельштам ориентировался не только на своего современника, но и на литературную традицию, творчески переосмысленную самим Пастернаком. В этой связи следует подчеркнуть, что именно в 1930-е годы Мандельштам читал Клопштока ${ }^{60}$. Переклички с ранним текстом Пастернака не мотивированы просто зимней обстановкой стихотворения или их близостью к темам и стилю самого Белого ${ }^{61}$, но являются прежде всего отсылкой к образу поэта-конькобежца, который Клопшток создал, а Мандельштам, видимо, узнал в стихах Пастернака. Это восприятие поэзии как экзистенциального опыта хорошо вписывается в поминальные стихи 1934 г., где смерть Белого предстает как реализация смерти Поэта. Благодаря отсылке с одной стороны к Клопштоку - при посредстве Пастернака, - с другой же - к Пушкину [СурАт 2003: 170-171], образ Белого приобретает более общие черты, и цикл, по собственному признанию Мандельштама ${ }^{62}$, предвещает также участь своего автора.

Итак, и Пастернак, и Мандельштам подхватывают у Клопштока вложенные в образ конькобежца размышления о сути творчества и о судьбе художника, которые тесно связаны со смертью. Однако эта тема у них отражается по-разному. Для раннего Пастернака искусство призвано восхвалять жизнь и обеспечивать возрождение действительности; в

59 Замечание О. Ронена цитируется в кн. [PoLLAK 1995: 182, прим. 123].

60 "В Армении О. М. вернулся к немцам и в тридцатых годах усиленно их покупал [. . .] Завел он и Клопштока, потому что, как он говорил, это звучит, как орган” [МАНДЕЛЬШТАМ Н. 1999: 288].

61 Гинзьург [1974: 393] в образе конькобежца видит зимний вариант столь характерной для Белого темы танца: “«Образуемых вновь падежей» - это словотворчество Белого, конькобежец же он потому, что он человек, - как говорит Цветаева, - в танце «смыслов, слов. .. фалд». А раз он конькобежец, то и от падежей идет морозная пыль и т. д." [ПоляковА 1992: 147] связывает это уподобление с языковым творчеством поэта: лингвистические виражи Белого позволяют “приравнять его к конькобежцу, делающему на льду сложные фигуры”. К тому же исследовательница отмечает, что вообще ассоциация Белого с зимой обусловлена разными факторами: во-первых, зимние реалии играют важную роль в поэзии Белого и появляются также в названиях некоторых его произведений (“Северная симфония” и “Кубок метелей”); во-вторых, это время года традиционно связана с тематикой смерти, и наконец, именно в этот период, в январе, скончался поэт.

62 "На сопереживание построен весь цикл Андрею Белому [. . . То Только тогда Мандельштаму стала совершенно ясна тема соумирания, сочувствия смерти другого как подготовки к собственному концу. Вот тогда-то я и говорила ему: «Что ты себя сам хоронишь?» - а он отвечал, что надо самому себя похоронить, потому что неизвестно, что еще предстоит" [МАндЕльштАм Н. 1990: 321]. 
этом ракурсе смерть понимается скорее абстрактно, как перспектива творческого увековечения мира и самого художника. Для позднего Мандельштама значение смерти задается вереницей гибелей таких писателей, как Н. Гумилев, А. Блок, Андрей Белый: смерть оказывается конкретным экзистенциальным условием жизни любого поэта.

\section{Библиограсрия}

АФАНАСьев 1995, 1-3

АФАнасьев А. Н., Поэтические воззрения славян на природу, 1-3, Москва, 1995 [1-е изд.: Москва, 1865-1869].

\section{БУХШТАБ 2000}

БУхштАБ Б. Я., “Пастернак. Критическое исследование”, in: IDEM, Фет и другие. Избранные работы, сост., вступ. ст., подгот. текста М. Д. ЭльзонА при участии А. Е. БАРЗАХА, С.-Петербург, 2000, 281-347.

ВЯЗЕМСКИЙ 1929

ВязЕмский П. А., Старая записная книжка, Ленинград, 1929.

\section{ГинзБург 1974}

Гинзьург Л. Я., О лирике, 2-е изд., доп., Ленинград, 1974.

\section{ГОРЕЛИК 2000}

Горелик Л. Л., Ранняя проза Пастернака: Мифо творении, Смоленск, 2000.

Жолковский 2011

Жолковский А. К., “Место окна в мире Пастернака”, in: IDEM, Поэтика Пастернака. Инварианты, структуры, интертексты, Москва, 2011, 27-64.

МАНДЕЛЬШТАМ 1978

МАндЕЛЬШтАм О. Э., Стихотворения, Ленинград, 1978.

$$
\text { 2009-2011, 1-3 }
$$

МАНДЕЛЬШТАм О. Э., Полное собрание сочинений и писем, 1-3, Москва, 2009-2011.

МАНДЕЛЬШТАМ Н. 1990

МАНДЕЛЬШТАМ Н. Я., Вторая КНИга, Москва, 1990. 1999

МАНДЕЛЬШТАм Н. Я., Воспоминания, Москва, 1999.

ПАСТЕРНАК 2003-2005, 1-11

ПАСТЕРНАК Б. Л., Полное собрание сочинений с приложениями, 1-11, Москва, 2003-2005.

ПАСТЕРНАК А. 2002

ПАСТЕРНАК А. Л., Воспоминания, Москва, 2002.

ПАСТЕРНАК Е. 1997

ПАСТЕРНАК Е. Б., Борис Пастернак. Биография, Москва, 1997.

ПАСТЕРНАК Л. 1975

ПАСТЕРНАК Л. О., Записи разных лет, Москва, 1975.

ПоляковА 1992

Полякова С. В., Осип Мандельштам: наблюдения, интерпретации, неопубликованное и забытое, Ann Arbor, 1992.

РАЕВСКАЯ-ХЬЮЗ 1994

РАЕВСКАЯ-ХьЮЗ О., “О самоубийстве Маяковского в Охранной Грамоте Пастернака”, in: K. Polivanov, I. Shevelenko, A. Ustinov, eds., Themes and variations. In Honor of 
Lazar Fleishman / Темы и вариации: сборник статей и материалов к 50-летию Лазаря Флейшмана (= Stanford Slavic Studies, 8), 1994, 141-152.

СПИВАК 2008А

СПивак М., “О. Э. Мандельштам и П. Н. Зайцев (К вопросу об истории, текстологии и прочтении стихотворного цикла «Памяти Белого»), in: И. ДЕлЕкторскАя,

О. ЛЕКмАНОв, Д. МАмЕДОвА, П. НЕРЛЕР, ред., Сохрани мою речъ, 4/1, Москва, 2008, 513-546.

2008Б

СпивАК М., “«Непонятен, понятен, невнятен. . .»: «темные места» в стихотворениях

O. Э. Мандельштама на смерть Андрея Белого”, in: W. G. Weststeijn, ed., Дело Авангарда / The Case of the Avant-Garde, Amsterdam, 2008, 25-42.

СурАт 2003

СурАт И., “Смерть поэта. Мандельштам и Пушкин”, Новый мир, 3, 2003, 155-173.

ФЛЕЙШМАН 1979

ФлЕЙшмАн Л., “О гибели Маяковского как «литературном факте». Постскриптум к статье Б. М. Гаспарова”, in: L. Fleishman, O. Ronen, D. SegAl, eds., Slavica Hierosolymitana, 4, Jerusalem, 1979, 126-130.

2003

ФлЕйшмАн Л., Борис Пастернак в двадизатые годы, С.-Петербург, 2003 [1-е изд.:

München, 1980].

Albert 1994

AlBeRT C., "Dichten und Schlittschuhlaufen: Eine poetologische Betrachtung von Klopstocks

Eislaufoden," Lessing Yearbook, 26, 1994, 81-92.

AROUTUNOVA 1979

Aroutunova B., “Земля и небо. Наблюдения над категориями пространства и времени в ранней лирике Пастернака", in: Boris Pasternak 1890-1960. Colloque de Cerisy-la-Salle (11-14 septembre 1975), Paris, 1979, 195-224.

BEDENK 2004

BEDENK J., Verwicklungen. William Hogarth und die deutsche Literatur des 18. Jahrhunderts (Lessing, Herder, Schiller, Jean Paul), Würzburg, 2004.

BROWNING 1978

BRownING R. M., German Poetry in the Age of Enlightenment. From Brockes to Klopstock, University Park, 1978.

EvANS-ROMAINE 1997

Evans-Romaine K., Boris Pasternak and the Tradition of German Romanticism (= Slavistische Beiträge, 344), München, 1997.

Goethe 1970

GoETHE J. W., Werke in zehn Bänden, 7, Zürich, 1970. 1985

Goethe J. W., Sämtliche Werke nach Epochen seines Schaffens, 16, München, 1985.

HILLIARD 1987

Hilliard K., Philosophy, Letters, and the Fine Arts in Klopstock's Thought, London, 1987. 1989

HiLLIARD K., "Klopstock in den Jahren 1764 bis 1770: metrische Erfindung und die Wiedergeburt der Dichtung aus dem Geiste des Eislaufs," Jahrbuch der Deutschen Schiller Gesellschaft, 33, 1989, 145-184.

KLOPSTOCK 1988

KLOPStоcк F. G., Briefe 1753-1758, Berlin, New York, 1988. 
2010

KLopstock F. G., Oden, Berlin, New York, 2010.

LEE 1980

LeE M., "The Imperiled Poet: Images of Shipwreck and Drowning in Three Klopstock's Odes," Lessing Yearbook, 12, 1980, 43-61. 1999

LeE M., Displacing Authority: Goethe's Poetic Reception of Klopstock, Heidelberg, 1999.

NÖLDEKE 1986

NöLDEKE E., Boris Leonidovič Pasternak und seine Beziehungen zur deutschen Kultur, Tübingen, 1986.

POLLAK 1995

Pollak N., Mandelstam the Reader, Baltimore, London, 1995.

RONEN 1983

Ronen O., An Approach to Mandel'štam, Jerusalem, 1983.

SALYS 1992

SALYs R., “Boris Pasternak and His Father's Art,” Oxford Slavonic Papers, 25, 1992, 120-135.

SHEIKHOLESLAMI 1985

Sheikholeslami E. A., Der Deutsche Einfluss im Werke von Boris Pasternak, Ann Arbor, 1985.

SIMEK 1996

Simek R., Dictionary of Northern Mythology, trans. by A. Hall, St. Edmunds, Suffolk, 1996.

STRICH 1970

STRICH F., Die Mythologie in der deutschen Literatur von Klopstock bis Wagner, 1, Bern, München, 1970.

THAYER 1973

THAYER T. K., "Klopstock and the literary Afterlife," Literaturwissenschaftliches Jahrbuch, 14, $1973,183-208$ 1980

ThAYeR T. K., "Rhetoric and the Rethorical in Klopstock's Odes," Euphorion. Zeitschrift für Literaturgeschichte, 74/4, 1980, 335-359. 1981

THAYER T. K., "Intimation of Immortality: Klopstock's Ode «Der Eislauf»," in: Goethezeit: Studien zur Erkenntnis und Rezeption Goethes und seiner Zeitgenossen. Festschrift für Stuart Atkins, Bern, 1981, 31-43.

\section{References}

Albert C., "Dichten und Schlittschuhlaufen: Eine poetologische Betrachtung von Klopstocks Eislaufoden," Lessing Yearbook, 26, 1994, 81-92.

Aroutunova B., "Zemlia i nebo. Nabliudeniia nad kategoriiami prostranstva i vremeni $\mathrm{v}$ rannei lirike Pasternaka," in: Boris Pasternak 1890-1960. Colloque de Cerisy-la-Salle (11-14 septembre 1975), Paris, 1979, 195-224.

Bedenk J., Verwicklungen. William Hogarth und die deutsche Literatur des 18. Jahrhunderts (Lessing, Herder, Schiller, Jean Paul), Würzburg, 2004.
Browning R. M., German Poetry in the Age of Enlightenment. From Brockes to Klopstock, University Park, 1978.

Bukhshtab B. Ya., Fet i drugie. Izbrannye raboty, M. D. Elzon, A. E. Barzakh, eds., St. Petersburg, 2000.

Evans-Romaine K., Boris Pasternak and the Tradition of German Romanticism (= Slavistische Beiträge, 344), München, 1997.

Fleishman L., "O gibeli Maiakovskogo kak 'literaturnom fakte.' Postskriptum k stat'e B. M. Gaspa- 
rova," in: L. Fleishman, O. Ronen, D. Segal, eds., Slavica Hierosolymitana, 4, Jerusalem, 1979, 126-130.

Fleishman L., Boris Pasternak in the Twenties, St. Petersburg, 2003.

Ginzburg L. Ya., O lirike, 2nd ed., Leningrad, 1974.

Gorelik L. L., Ranniaia proza Pasternaka: Mifo tvorenii, Smolensk, 2000.

Hilliard K., Philosophy, Letters, and the Fine Arts in Klopstock's Thought, London, 1987.

Hilliard K., "Klopstock in den Jahren 1764 bis 1770: metrische Erfindung und die Wiedergeburt der Dichtung aus dem Geiste des Eislaufs," Jahrbuch der Deutschen Schiller Gesellschaft, 33, 1989, 145-184.

Lee M., "The Imperiled Poet: Images of Shipwreck and Drowning in Three Klopstock's Odes," Lessing Yearbook, 12, 1980, 43-61.

Lee M., Displacing Authority: Goethe's Poetic Reception of Klopstock, Heidelberg, 1999.

Nöldeke E., Boris Leonidovič Pasternak und seine Beziehungen zur deutschen Kultur, Tübingen, 1986.

Pasternak E. B., Boris Pasternak. Biografiia, Moscow, 1997.

Poliakova S. V., Osip Mandel'shtam: nabliudeniia, interpretatsii, neopublikovannoe $i$ zabytoe, Ann Arbor, 1992.

Pollak N., Mandelstam the Reader, Baltimore, London, 1995.

Raevsky Hughes O., "O samoubiistve Maiakovskogo v Okhrannoi Gramote Pasternaka," in: K. Polivanov, I. Shevelenko, A. Ustinov, eds., Themes and variations. In Honor of Lazar Fleishman (= Stanford Slavic Studies, 8), 1994, 141-152.

Ronen O., An Approach to Mandel'štam, Jerusalem, 1983.
Salys R., "Boris Pasternak and His Father's Art," Oxford Slavonic Papers, 25, 1992, 120-135.

Sheikholeslami E. A., Der Deutsche Einfluss im Werke von Boris Pasternak, Ann Arbor, 1985.

Simek R., Dictionary of Northern Mythology, trans. by A. Hall, St. Edmunds, Suffolk, 1996.

Spivak M., "O. E. Mandel'shtam i P. N. Zaitsev (K voprosu ob istorii, tekstologii i prochtenii stikhotvornogo tsikla 'Pamiati Belogo'),' in: I. Delektorskaya, O. Lekmanov, D. Mamedova, P. Nerler, eds., Sokhrani moiu rech', 4/1, Moscow, 2008, 513-546.

Spivak M., “Neponiaten, poniaten, nevniaten. . .' 'temnye mesta' $\mathrm{v}$ stikhotvoreniiakh O. E. Mandel'shtama na smert' Andreia Belogo," in: W. G. Weststeijn, ed., The Case of the Avant-Garde, Amsterdam, 2008, 25-42.

Strich F., Die Mythologie in der deutschen Literatur von Klopstock bis Wagner, 1, Bern, München, 1970.

Surat I., "Smert' poeta. Mandel'shtam i Pushkin," Novyi mir, 3, 2003, 155-173.

Thayer T. K., "Klopstock and the literary Afterlife," Literaturwissenschaftliches Jahrbuch, 14, 1973, 183-208.

Thayer T. K., "Rhetoric and the Rethorical in Klopstock's Odes," Euphorion. Zeitschrift für Literaturgeschichte, 74/4, 1980, 335-359.

Thayer T. K., "Intimation of Immortality: Klopstock's Ode «Der Eislauf»," in: Goethezeit: Studien zur Erkenntnis und Rezeption Goethes und seiner Zeitgenossen. Festschrift für Stuart Atkins, Bern, 1981, 31-43.

Zholkovsky A. K., Poetika Pasternaka. Invarianty, struktury, interteksty, Moscow, 2011.

Roberta Salvatore, R. T. D.

Università degli Studi di Messina

Dipartimento di civiltà antiche e moderne

Viale Annunziata, Messina 98168

Italia/Italy

robertasalvatore@mail.ru

Received May 22, 2017 